\title{
RELATIONS, INTERACTIONS AND NETWORKS OF CULTURAL TOURISM STAKEHOLDERS IN RURAL AREAS OF VOJVODINA
}

\author{
Nataša Pavlović ${ }^{1}$, Sandra Medić², Aleksandra Tešičc
}

\begin{abstract}
Summary
Contemporary trends, which are characterized by a very strong level of competition and the maturity of the market, become more than ever essential for success of tourist destinations. Rural areas in Vojvodina, because of its authentic atmosphere and multiculturalism, have significant advantages for cultural tourism. Each participant who creates a tourism product in today's competitive environment aims to have a strong focus on customer satisfaction, which indicates the necessity of adopting the concept of total relationship marketing.

The aim of this paper is to show how cultural institutions, souvenir craftsmen, tourism organizations, travel agencies and other stakeholders achieve cooperation and apply modern concept of total relationship marketing for the purposes of satisfying the needs of tourists.

The paper will explore the fundamental postulates of relationship marketing applied by key stakeholders of cultural tourism in rural areas, and will get reference results on relations, interactions and networks.
\end{abstract}

Key words: total relationship marketing, cultural tourism, rural areas.

JEL: M31, Q01, Z1

\section{Introduction}

Rural destinations, where the integration tourism, farm, local resources, culture and natural environment are present, are attractive, as culture and tourism become resources for socioeconomic development of these areas (Mc Donald, Jolliffe, 2003). Serbia has around $85 \%$ rural areas, which makes it one of the least urbanized countries in Europe. Rural

1 Nataša Pavlović, M.A., deputy director, Tourism organisation of Vojvodina, Bulevar Mihajla Pupina no. 6, 21000 Novi Sad, Serbia, Phone: +381 63444 184, E-mail: nts.pavlovic@gmail.com

2 Sandra Medić, M.Sc, expert independent associate, Tourism organisation of Vojvodina, Bulevar Mihajla Pupina no. 6, 21000 Novi Sad, Serbia, Phone: +381 63535 599, E-mail: medics.ns@gmail.com

3 Aleksandra Tešić, Ph.D., Associate Professor, Business Academy University, Faculty of Economics and Engineering Management, Cvećarska 2, 21000 Novi Sad, Phone: +381 692000 954, E-mail: prof.aleksandra.tesic@gmail.com

EP 2015 (62) 2 (481-495) 
areas in Serbia, as well as in Vojvodina have shortage of available jobs, which influences depopulation and abandonment of the villages. The role of tourism, and its' multiplicative effects gives the opportunities for employing the population in additional activities, beside agriculture. Also, this way the tourism involves the community in keeping traditional customs and products. Rural tourism, as a combination of different forms of tourism that showcase rural life, art, culture and heritage in rural locations, is extremely suitable for diversifying Serbian rural economy. One of the reasons for traveling to a rural destination is to get familiar with local population and their tradition. Also tourists, who are visiting those kinds of destinations, usually take part in different activities like recreation, making handcrafts or they are participants in some local event. The customs and cultural heritage of local community have an important role in creating such a touristic product.

According to Tylus (2012) the role of culture in development should be treated as multilayered: on the one hand as an intrinsic value, secondly as a real factor of regional development leading to increased attractiveness of regions for tourists, residents and investors, thirdly, as an active factor of social development based on knowledge, tolerance and creativity.

Because it is quite a complex demand to be met, cultural tourism has a lot of stakeholders with diverse interests. On one hand, there are accommodation, restaurants, shops, cultural institutions, cultural centers, travel agencies, tourism organizations etc. On the other hand, there is a local community and local government. Only together they can provide authentic offer for visitors and tourists.

The potential of tourism development in Vojvodina lies in rich and varied resources, which consist of natural, cultural and historical attractions. In the recent years, traditional farm house called "salaš" became the most popular tourist attraction, with the authentic appearance. Today they are keepers of their time and a traditional way of life, and as such are attracting the attention of tourists. These farm houses, and villages of Vojvodina in general, are suitable for family and active holidays, and for people who love to spend time outdoors. The offer is created with authentic accommodation, local cuisine and traditional events. The rural areas in Vojvodina are filled with ethno-social features, which are special and very attractive for the group of cultural tourist and very important reason why people visit farm houses and villages of this region.

Large number of villages in Vojvodina is in the vicinity of valuable cultural and historical monuments. Regarding the rich cultural tradition, rural areas offer a strong cultural identity, which could be used as an important developmental factor of tourism and villages (Stojanović, 2008). Events and festivals are essential for the cultural identity of local community. In Vojvodina, there are more than 1,000 events during one year and most of them are originally created to celebrate the various local events and traditions, such as harvest, gastronomy and customs. Initially they were planned to serve and entertained local people, but with the awareness of economic benefits, the majority of rural communities could expand the scope of activities which could bring visitors to the events. Economic potential of cultural tourism could be optimally used through strong 
establishment of relations, interactions, and networks between adequate tourism offer and appropriate consumers.

Successful development of cultural tourism in rural areas of Vojvodina depends of strategic collaboration which includes wide spectrum of stakeholders. Effective partnerships of private and public sector are a base for sustainable development.

Relationship marketing has become a term that is widely used in recent years. It is the subject of serious discussion and research by scholars, as well as those who use it in marketing practice. The last decade of XX century marked the importance of the relationship, i.e. relationships in marketing theory and practice, and it was in this period that marketing relationships established as a term, which is primarily related to marketing services.

The lack of classic marketing paradigm is that it starts from marketing as primarily marketing physical products. This approach showed its weaknesses, especially in the areas of marketing services (Ljubojević, 2002). For this reason, many scientists have begun to deal with the marketing of services, especially since the period of the nineties of the XX century was marked by the dominant role of services in the creation of the gross domestic product of many countries.

Relationship marketing represents paradigm of changes which take place in marketing practice. Changes are mainly related to shift from the focus at transactions to the focus at relationships. Relationship approach points out relationship continuity which is to be developing between organization and its consumers, with main focus at consumer services and standards of quality. Application of relationship marketing assumes developing relationships not only with consumers but also with distributors, suppliers, public institutions, individuals, etc. (Ćosić, Đurić, 2010).

Relationship marketing has become a unifying force within marketing. Mattsson (1997) suggested that here at last there was a concept within marketing research that served as the generic context for all marketing transactions, whether products or services, consumer or industrial. This viewpoint was supported by Sheth and Parvatiyar (2000) who suggest that the scope of relationship marketing was wide enough to cover the entire spectrum of marketing's sub-disciplines including “channels, business-to-business marketing, services marketing, marketing research, customer behavior, marketing communications, marketing strategy, international marketing and direct marketing". Grönroos (1996) believed that relationship marketing represented the biggest change in 50 years, in effect "taking marketing back to its roots".

Relationship marketing (RM) is usually defined as an approach to develop long-term loyal customers and thus increasing profitability. Definition of Gummesson is more generic: Relationship marketing is interaction in networks of relationships (2008).

This paper considers cultural aspects of rural tourism potentials in Vojvodina that holds a vast attractive heritage and creates the conditions for preservation of structural and spiritual identity of the villages in this region. The aim of this paper is to emphasize the 
importance of cooperation between key stakeholders and their adoption of relationship marketing concept in order to satisfy visitors of cultural heritage in rural areas in Vojvodina. In this way, through the contemporary paradigm, possibilities will be suggested for cultural tourism enhancement and rural development.

\section{Theoretical background}

Potential tourists in rural tourism, who are in most cases from the urban areas, define the rural character of the area primarily by the level of traditionalism, as well as general social values that do not exist in urban centers. Rural areas are characterized as areas with strong sense of community, local, not a cosmopolitan way of life, which is "slower", less materialistic and less "complicated" than in urban areas (Popesku, 2014). The growing interest of modern tourists for the cultural heritage emphasizes the importance of these characteristics of rural areas.

There are lots of definitions of cultural tourism. Some of them are derived from tourism, and some of them are based on experience of tourists. On the one hand, they emphasize objects of cultural heritage, their consumption and need for protection, and on the other, they involve tourists themselves and their motivation and experiences. In previous decades there have been many attempts to produce definitions of cultural tourism, but the essence remains fairly simple: cultural tourism involves cultural consumption by people while travelling (Richards, 2013).

The important characteristics of rural tourism are tourists' life in a rural community, participation in daily activities of the hosts, exploring the customs of the villagers, their folklore, music and cultural values. Therefore, connection of rural tourism with cultural tourism is very clear.

Two effects of investments undertaken in the field of culture can be distinguished. One of them is the expansion of the regional economic base that comprises an impulse for further development. This development is expressed by improvement of the market and marketing situation of existing commercial entities (e.g. a positive change in a region's image), improvement in the standard of living of residents (expansion of the cultural infrastructure and increased access to culture) as well as an increase in the number of jobs associated with the investment realization process, and then with the functioning of new elements of a region's fixed assets. The second effect results from the stimulating impact of public expenditures by income - demand multipliers. Increasing the income of commercial entities and households, these expenditures stimulated additional demand, which has a large impact on local markets of goods and services (Tylus, 2012).

Local culture provides a sense of identity for communities and residents. This identity facilitates mutual understandings, traditions, and values that are all central to identifying plans of action to improve overall well-being of the community. Culture contributes to building a sense of local identity and solidarity. It influences the confidence that communities have for coming together to address specific needs and problems. This local commitment among residents, regardless of economic or political conditions, can serve as 
a valuable tool in shaping the effectiveness of development options and local actions. Such commitment, based on culture and common identity, can be seen as a potentially important tool in sustaining local government, development, and social improvement efforts. The inclusion of culture into community and economic development models can take many shapes and forms. Culture can serve as the central focus. Tourism would be included as well as other efforts that focus largely on the promotion, preservation, or enhancement of local or regional cultures. Examples of cultural preservation or efforts focusing solely on culture are often seen in relation to tourism and conservation efforts. This includes renovation of villages (architectural rehabilitation), highlighting the architectural heritage of an area (restoring historic sites to serve as a focal point for tourists), cultural venues (local heritage centers and traditional cultural events), traditional craft and artistic skills (development of industry and employment based on producing crafts that symbolize local culture), and cultural-based entertainment and cultural dissemination (organization of cultural activities, festivals, and permanent exhibitions) (Brennan et al., 2005).

According to McKercher (2004) museums are the most popular cultural attractions, together with galleries and monuments. They have very important role in keeping cultural diversity, education, social cohesion, personal development. They also promote an integrated approach to cultural heritage and preserve the community's identity. They also stimulate the economy, increase employment and income. Unfortunately in the past 20 years, due to the crisis in Serbia and Vojvodina, cultural institutions and cultural identity in general have been disregarded despite all of its potential.

Cultural tourism is specific in the terms of a large proportion of tourists' involvement with tourists' consumption and experience in creation of tourism product (Hadžić, 2005). This character of product in cultural tourism, which is mostly partial tourism product, has clear implications for the application of the theory of total relationship marketing, created by Swedish scientist Gummesson (2008).

Relationship marketing theory suggests that the relations are main factor that contribute to the quality of marketing transactions. Traditional markets are extremely powerful, but they also have huge limitations. Appropriate "people to people exchanges" are much richer than the exchange market. Every time when people establish connection with people, or community (rather than market), they do not exchange money for goods only, they share ideas, opinions, information, and beliefs. They also tend to form strong bonds, relationships, loyalty, feelings, commitments, etc. They begin to share and create value. Therefore people whose values are most compatible with those around them, tend to form the most powerful and successful relationships with other people. In literature review it appears that there are many variations in the types of relationships that are believed to exist between the buyer and the seller, and their typology depends on the industry, company, customers themselves, and many other factors. So Palmatier (2008) states that customer relationships do not affect equally all the outcomes of exchange. Gummesson (2008) makes a valiant attempt and tried to classify many of the relationships in his $30 \mathrm{Rs}$ model (Table 1). The philosophy of the concept of the marketing mix has evolved, so it has to date developed thirty defining relations, which represents the new structure of marketing thinking. Classic marketing EP 2015 (62) 2 (481-495) 
relationships (R1-R3) are relations that have so far dealt with the theory of marketing. Special marketing relationships (R4-R17) are partly classic aspects of relations, with some innovations (such as a "customer as member" and other). Mega relationships (R18-R23) are the basis for relationship marketing economy and society, including the mega marketing activities (lobbying, public opinion, and political power), mega alliances (large corporations and associations that characterize the new stage of marketing) and social relations (such as friendship and ethnicity). Nano relationships (R24-R30) are relationships through which the market relations merged to relations within the company.

Table 1. The 30 Relationships of RM - the 30 Rs

\begin{tabular}{|c|c|}
\hline \multicolumn{2}{|c|}{ Classic market relationships } \\
\hline 1 & Supplier and customer \\
\hline 2 & The customer - supplier - competitor triangle \\
\hline 3 & Network - distribution channels \\
\hline \multicolumn{2}{|c|}{ Special market relationships } \\
\hline 4 & Full-time marketers and part-time marketers \\
\hline 5 & Customer and service provider \\
\hline 6 & Many-headed customer and many-headed supplier \\
\hline 7 & Relationship to the customer's customer \\
\hline 8 & Close versus distant relationship \\
\hline 9 & Dissatisfied customer \\
\hline 10 & Monopoly relationship: customer or supplier as prisoner \\
\hline 11 & Customer as "member" \\
\hline 12 & Electronic relationship \\
\hline 13 & Para-social relationships, with symbols and objects \\
\hline 14 & Non-commercial relationship \\
\hline 15 & The green relationship \\
\hline 16 & The law-based relationship \\
\hline 17 & The criminal network \\
\hline \multicolumn{2}{|c|}{ Mega relationships } \\
\hline 18 & Personal and social networks \\
\hline 19 & Mega marketing - the real "customer" is not always found in the marketplace \\
\hline 20 & Alliances change the market mechanism \\
\hline 21 & The knowledge relationship \\
\hline 22 & Mega alliances change the basic conditions for marketing \\
\hline 23 & Mass media relationship \\
\hline \multicolumn{2}{|c|}{ Nano relationships } \\
\hline 24 & Market mechanisms are brought inside the company \\
\hline 25 & Internal customer relationships \\
\hline 26 & Quality providing a relationship between operations management and marketing \\
\hline 27 & Internal marketing - relationships with the employee market \\
\hline 28 & Two-dimensional matrix relationship \\
\hline 29 & Relationship to external providers of marketing services \\
\hline 30 & Owner and financier relationship \\
\hline
\end{tabular}

Source: Gummesson, 2008. 
Concerning that all Rs are not applicable to each sector, company and each situation, in this paper the authors have made a specific relationship portfolio for the marketing plan of key stakeholders of cultural tourism in rural areas. As Gummesson suggested (2008), we tried to look at marketing as relationships, networks and interaction. This led to the identification of prerequisites for relationship marketing orientation of key stakeholders of cultural tourism in rural areas in Vojvodina region. These prerequisites are customer orientation, e-marketing, internal marketing and "green marketing" and corporate social responsibility (CSR).

We will point out some of the details of the following relations, which are in our opinion of great importance for the successful total relationship marketing in cultural tourism of rural areas. Certainly those are: relationships with tourists, relationships with employees (internal marketing), relations between partners, e-relations and environmental and health issues and CSR.

This is due to the fact that relationship marketing raises the need for customer orientation, and customer orientation raises the need for customer-oriented employees. The latter can be achieved through internal marketing. Customer orientation implementation doesn't exist without customer oriented employees, because they are the ones that have to make it happen. If there were no customer orientation (which leads to customer satisfaction), there would be no relationship marketing because unsatisfied customers will never develop good relationships with the business (Engel et al., 1995).

Also, strong partnership, which is based on personal network and interaction between key stakeholders builds strong long-term relations and improves business and strengthens tourist destinations (in this case cultural heritage in rural areas of Vojvodina).

IT creates a new tool for every sector and for tourism as well, and offers new opportunities for marketers. Most people find new destinations through Internet. Electronic relationships or e-relationships embrace relationships, networks and interaction based on IT. Like e-CRM, e-relationships have appeared throughout the text, naturally as today they exist in some form in all company, consumer and citizen activities (Gummesson, 2008). The research uncovers findings that elevate possibilities for adoption of "green marketing" relative to sustainable tourism business.

\section{Methodology and Data Collection}

In order to conduct this survey, the Questionnaire was distributed via e-mail to 327 companies across the Vojvodina region during March and April 2014. It included tourism organizations, receptive travel agencies, museums, galleries, cultural centers, ethno houses, civil organizations, event managers, farmhouses, vineries, craftsmen and accommodation facilities in rural areas. Potential respondents were given a brief description of the meaning of the survey, and it was emphasized that this research included only visitors who were coming to rural areas for the cultural motives. Each respondent was then asked to answer the questions in the questionnaire on the basis of his or her personal experience. 
According to relevant literature and informal interviews with experts in cultural and rural tourism, authors developed a Questionnaire which was designed and divided into three sections. The questions were structured and close-ended. The first section was about basic company data, the type of company, number of employees and business existence. The second part was about socio-demographic data of respondents, gender, age, experience, education, occupation and position in the company. The final, third part was about relations with visitors, relations and interaction with key stakeholders and networks. The part "relations with visitors" included questions about customer orientation. Then part "relations and interaction with key stakeholders" included questions about database about visitors, loyalty programs, connections and co-operations with stakeholders in cultural tourism and consideration of social environment. The part about networks included questions about usage of personal and professional connections in business, lobbying, inter-sector cooperation, clustering or making alliances and cooperation with media.

The choice of the Questionnaire design was based on the focus of the research. The focus of the research was to measure the attitude of the key stakeholders towards the relationship marketing orientation concept, some of the components and its implementation as base for the developing a guideline for successful relationship marketing orientation (Giljam, Granberg, 1993). All items were assessed on a 5-point Likert-type scales ranging from 1 (strongly disagree) to 5 (strongly agree).

Analyses were conducted to assess reliability and validity of the research (Table 6.). The Cronbach's alpha for each of the three components ranged from 0.857 to 0.898 , which are regarded as acceptable for basic research (Nunnally, 1978). Since all $\alpha$ values are over 0.85 , the constructs used are considered as reliable.

\section{Results and discussion}

Of the 327 questionnaires that were distributed, 91 completed questionnaires were returned (a response rate of 28.4\%). The Questionnaire was distributed to 33 tourism organizations, 17 receptive travel agencies, 18 museums, 9 galleries, 25 cultural centers, 26 ethno houses, 103 event managers, NGO's and civil organizations, 35 farmhouses, 26 craftsmen, 44 accommodation and food and drink facilities in rural areas. The percentage of types of companies among respondents can be seen in the Table 2.

Table 2. Percentage of types of companies among respondents

\begin{tabular}{|l|l|l|}
\hline Respondents & Frequency & Percent (\%) \\
\hline Cultural centers & 11 & 12.1 \\
\hline Museums & 7 & 7.7 \\
\hline Galleries & 2 & 2.2 \\
\hline Ethno houses & 4 & 4.4 \\
\hline Tourism organizations & 16 & 17.6 \\
\hline Receptive travel agencies & 6 & 6.6 \\
\hline Farmhouses & 2 & 2.2 \\
\hline NGO, civil associations & 12 & 13.2 \\
\hline Accommodation facilities & 8 & 8.8 \\
\hline
\end{tabular}




\begin{tabular}{|l|l|l|}
\hline Respondents & Frequency & Percent (\%) \\
\hline Food and drink facilities & 11 & 12.1 \\
\hline Event managers & 6 & 6.6 \\
\hline Craftsmen & 5 & 5.5 \\
\hline Other & 1 & 1.1 \\
\hline Total & 91 & 100 \\
\hline
\end{tabular}

Source: Pavlović, Medić, 2014.

Among respondents, 76\% were represented micro and $16.5 \%$ small entrepreneurs. Their companies are relatively new or they have long tradition, $37.4 \%$ was the companies with experience up to 5 years, $27.5 \%$ was more than 21 years old, from 6 to 10 years there were $24.2 \%$ companies and finally with $7.7 \%$ was the companies with experience from 11 to 20 years.

Most employees in the survey are women (56.2\%), whereas there are $43.8 \%$ men. Out of 91 respondents who were included in the analysis, 42.2\% are aged between 36 and 45 . As far as education level is concerned, there are $37.4 \%$ who have high school education and $29.7 \%$ graduated from university. Then $36.4 \%$ have work experience in tourism lasting between 6 and 10 years. More detailed analysis can be seen in Table 4. Total sum of respondents, in the table below, vary for different characteristics of respondents (gender, age, education etc.) because in some questions we had missing data, but without any significant discrepancies.

Table 3. Selected socio-demographic characteristics of the samples

\begin{tabular}{|c|c|c|c|c|}
\hline Characteristics & Groups & Frequency & Percent & Valid Percent \\
\hline \multirow{3}{*}{ Gender } & man & 39 & 42.9 & 43.8 \\
\hline & woman & 50 & 54.9 & 56.2 \\
\hline & Total & 89 & 97.8 & 100 \\
\hline \multirow{6}{*}{ Age } & $18-35$ & 28 & 30.8 & 31.1 \\
\hline & $36-45$ & 38 & 41.8 & 42.2 \\
\hline & $46-55$ & 13 & 14.3 & 14.4 \\
\hline & \begin{tabular}{|l|}
$56-65$ \\
\end{tabular} & 8 & 8.8 & 8.9 \\
\hline & over 66 & 3 & 3.3 & 3.3 \\
\hline & Total & 90 & 98.9 & 100 \\
\hline \multirow{5}{*}{ Education level } & high school & 34 & 37.4 & 37.4 \\
\hline & bachelor & 25 & 27.5 & 27.5 \\
\hline & faculty & 27 & 29.7 & 29.7 \\
\hline & master/magister & 5 & 5.5 & 5.5 \\
\hline & Total & 91 & 100 & 100 \\
\hline \multirow{5}{*}{ Work experience } & $\geq 5$ years & 26 & 28.6 & 29.5 \\
\hline & 6-10 years & 32 & 35.2 & 36.4 \\
\hline & 11-20 years & 23 & 25.3 & 26.1 \\
\hline & $\leq 21$ years & 7 & 7.7 & 8.0 \\
\hline & Total & 91 & 100 & \\
\hline
\end{tabular}




\begin{tabular}{|c|c|c|c|c|}
\hline Characteristics & Groups & Frequency & Percent & Valid Percent \\
\hline \multirow{8}{*}{ Vocation } & manager & 15 & 16.5 & 16.5 \\
\hline & manager in tourism & 17 & 18.7 & 18.7 \\
\hline & economist & 21 & 23.1 & 23.1 \\
\hline & manager in culture & 2 & 2.2 & 2.2 \\
\hline & caterer & 5 & 5.5 & 5.5 \\
\hline & law & 3 & 3.3 & 3.3 \\
\hline & other & 28 & 30.8 & 30.8 \\
\hline & Total & 91 & 100 & 100 \\
\hline \multirow{7}{*}{$\begin{array}{l}\text { Position in } \\
\text { company }\end{array}$} & owner & 20 & 22 & 22.5 \\
\hline & high management & 31 & 34.1 & 34.8 \\
\hline & \begin{tabular}{|l|}
$\begin{array}{l}\text { medium and low } \\
\text { management }\end{array}$ \\
\end{tabular} & 12 & 13.2 & 13.5 \\
\hline & employees & 17 & 18.7 & 19.1 \\
\hline & \begin{tabular}{|l|} 
occasionally \\
employed
\end{tabular} & 3 & 3.3 & 3.4 \\
\hline & other & 6 & 6.6 & 6.7 \\
\hline & Total & 89 & 97.8 & 100 \\
\hline
\end{tabular}

Source: Pavlović, Medić, 2014.

This research gave positive results concerning adoption of three main characteristics of total relationship marketing. Regarding relations with visitors, most respondents gave the answer 4 (I agree) on Likert scale and we can conclude that those relations are an important part of marketing activities of key stakeholders of cultural tourism in rural areas of Vojvodina. Relations and interaction with others who are creating cultural tourism offer in rural areas are also valued as a significant activity (concerning that Mode=5, Mean=4.03). We can say that respondents adopted network as a marketing strategy according to the results $($ Mode=4, Mean=3.83). These results were confirmed by high ranking evaluation on the scales.

Table 4. Descriptive Statistic $(\mathrm{N}=91)$

\begin{tabular}{|l|l|l|l|l|l|}
\hline Principles of TRM & Minimum & Maximum & \multicolumn{1}{|c|}{ Mean } & Mode & Std. Deviation \\
\hline Relations & 1 & 5 & 4.21 & 4 & .739 \\
\hline Interactions & 1 & 5 & 4.03 & 5 & .633 \\
\hline Networks & 2 & 5 & 3.83 & 4 & .607 \\
\hline
\end{tabular}

Source: Pavlović, Medić, 2014.

For the purposes of determining the empirical relationship between variables and groups, we used the results of established correlations which are shown in Table 5 and 6 . For the purposes of this paper, we analyzed only statistically significant results. 
Table 5. The matrix of correlation coefficients

\begin{tabular}{|l|l|l|l|}
\hline \multicolumn{1}{|c|}{ Principles of TRM } & Size of company & Company existence & \multicolumn{1}{c|}{$\begin{array}{c}\text { Work experience of } \\
\text { respondents }\end{array}$} \\
\hline Relations with visitors & & $-.340^{* *}$ & $.226^{*}$ \\
\hline $\begin{array}{l}\text { Interactions with key } \\
\text { stakeholders }\end{array}$ & $-.323^{*}$ & \\
\hline Networks & $.218^{*}$ & \\
\hline $\begin{array}{l}* \text { *.Correlation is significant at the } 0.05 \text { level (2-tailed) } \\
* * \text {. Correlation is significant at the } 0.01 \text { level (2-tailed) }\end{array}$ \\
\hline
\end{tabular}

Source: Pavlović, Medić, 2014.

It was shown that the size of company correlates with the usage of network as marketing strategy. The bigger the company, the more personal and professional networks are established with other companies, institutions, investors, $\mathrm{NGO}$, media etc.

Concerning the correlation between relations with visitors and company existence, it could be seen that there is a significant correlation at the 0.01 level (2-tailed). This means that with increasing time of company existence (period of doing business) relations with visitors become weaker. That could be explained with the fact that older companies /organizations are less committed to establishing relations with visitors who are coming to rural areas for cultural reasons. They probably have loyal customers and well developed relations with them, so they put less effort to attract, maintain and established long-term relationships with visitors. The same situation is with the influence of company existence on interaction with key stakeholders (correlation is significant at the 0.05 level (2-tailed)). We assumed that older companies are less committed to interact with others, because they have already relatively developed those kinds of relations.

Finally it was shown that work experience of respondents correlate with usage of relations with visitors as marketing strategy (correlation is significant at the 0.05 level (2-tailed)). As expected, the respondents, who have more work experience in tourism, are more committed to the relations with visitors.

The scales of relations, interactions and networks measure aspects of the same phenomenon, so it was logical that they are highly correlated (Table 6).

Table 6. The matrix of correlation coefficients

\begin{tabular}{|l|l|l|l|}
\hline \multicolumn{1}{|c|}{ Principles of TRM } & \multicolumn{1}{c|}{ Relations } & \multicolumn{1}{c|}{ Interactions } & \multicolumn{1}{c|}{ Networks } \\
\hline Relations & $1(\alpha=0.860)$ & $.792^{* *}$ & $.462^{* *}$ \\
\hline Interactions & & $1(\alpha=0.898)$ & $.657^{* *}$ \\
\hline Networks & & & $1(\alpha=0.857)$ \\
\hline **. Correlation is significant at the 0.01 level (2-tailed) & \\
\hline
\end{tabular}

Source: Pavlović, Medić, 2014.

Relations with visitors and relations and interactions with key stakeholders have significant correlation (correlation is significant at the 0.01 level (2-tailed)). The more respondents use relations with visitors, the more they are establishing relations and 
interactions with key stakeholders. Almost the same situation is with two other scales. They all have high value of correlations and according to Cohen the values above 0.5 represent high correlations (1998).

\section{Conclusions}

In order to conduct this survey the Questionnaire was distributed to 327 companies across Vojvodina region during March and April 2014. It included main tourism stakeholders which are dealing with cultural tourism in rural areas, such as tourism organizations, receptive travel agencies, museums, galleries, cultural centers, ethno houses, civil organizations, event managers, farmhouses, vineries, craftsmen and accommodation facilities in rural areas of Vojvodina.

Our research findings provide support for our theoretical concept and predicted relationships, interactions and networks between key cultural tourism stakeholders in terms to improve cultural tourism offer and local development in rural areas. The main results have shown that they are aware of importance of using total relationship marketing in terms of improving their business. The older the company/organization the relations with visitors are weaker. This could be explained with the fact that they are less committed to establishing relations with visitors, who visit rural areas for cultural reasons, because they have probably loyal customers and well developed relations with them, so they put less effort to attract, maintain and establish long-term relationships with visitors. The same situation is with the influence of company existence to interaction with key stakeholders. We assume that older companies are less committed to interact with others, because they have already relatively developed those kinds of relations. Also, it was shown that work experience of respondents correlates with the usage of relations with visitors as marketing strategy. As expected, the employees, who have more work experience in tourism, were more committed to the relations with visitors. Finally, the bigger the company, the more personal and professional networks are established with other companies, institutions, investors, NGOs, media etc.

Due to small number of respondents and return of the questionnaires, the obtained results were only indicative and they could serve as a good example and possible starting point for further research. Also, our research included opinions and attitudes of key stakeholders of cultural tourism in rural areas without measuring usage of CRM. Through applying of CRM concept further research could analyze attitudes and perceptions of visitors in rural areas. The main goal could be their confirmation and evaluation of total relationship marketing adoption. Finally, we recommend more detailed investigation of adoption of 30Rs in companies or organization's marketing strategies.

Modern concept of total relationship marketing is used in many sectors which is result of globalization process and transformation of traditional to relational marketing. The main principles of this concept are customer relationship management and establishment of long term relations, interactions and networks with customers and other partners involved.

Complex tourism structure imposes the necessity of marketing orientation to total relationship marketing. As market becomes more competitive, a greater understanding of total relationship 
marketing will become more important. Cultural tourism is undoubtedly one of those types of tourism whose development includes a wide range of partners. Its successful development depends largely on their good cooperation.

Rural economies in Vojvodina are faced with a number of opportunities, also challenges in becoming more competitive and sustainable. Despite this fact, the cultural heritage and potentials of rural areas still were not sufficiently valued and promoted in the past, because there was no consensus between stakeholders within these destinations. Even they are aware of beneficiaries of usage and adoption of contemporary marketing concepts, still there is absence of real process of relations, interactions and network.

Rural tourism can help lead the way to a more diversified rural economy while creating jobs and increasing income, since tourism enhances the local economy by offering opportunities for locally-processed products, handicrafts and souvenirs. This requires balance between agricultural production and other economic activities, environmental protection, and social development. Sustainable rural tourism is one of the key sectors with strong potential for diversifying rural economy. In Vojvodina, in the past several years a movement has been developing toward sustainable rural tourism that tackles the threats of unmanaged tourism. Sustainable tourism views tourism within destination areas as a relationship between host areas and their communities and people, tourists, and the tourism industry. Sustainable tourism minimizes environmental and cultural damage, optimizes visitor satisfaction, maximizes long-term economic growth, and balances tourism growth potential and the conservation needs of the environment. The research results indicated that the familiarity of stakeholders in the modern marketing concept whose fundamental principles are based on relations, interactions and networks, should be the foundation and stronger directions for cultural tourism development and identity building of the region, and thus affect the local and economic development of rural areas in Vojvodina.

\section{References}

1. Brennan, M., Kumaran, M., Cantrell, R., Spranger, M. (2005): The Importance of Incorporating Local Culture into Community Development, University of Florida,

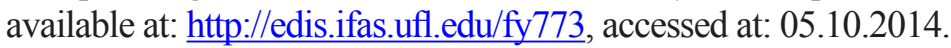

2. Cohen, J. W. (1988): Statistical power analyses for the behavioral sciences, $2^{\text {nd }}$ edition, Lawrence Erlbaum Associates, USA.

3. Ćosić, M., Đurić, M. D. (2010): Relationship marketing in the tourist services sector, UTMS Journal of Economics, vol. 1, no.1, pp. 53-60, University of Tourism and Management, Skopje, Macedonia.

4. Engel, J. F., Blackwell, R. D, Miniard, P. W (1995): Consumer behavior, $8^{\text {th }}$ Edition, Harcourt, Orlando.

5. Giljam, M., Granberg, D. (1993): Should we take don't know for the answer? Public opinion quarterly, Oxford Journals, vol. 57, issue 3, pp. 348-357, Oxford.

6. Grönroos, C. (1996): Relationship approach to the marketing function in service contexts,

EP 2015 (62) 2 (481-495) 
Journal of Business Research, vol. 29, no. 1, pp. 7-13, Elsevier, Boston.

7. Gummesson, E. (2008): Total Relationship Marketing, $3^{\text {th }}$ Edition, ButterworthHeinemann, Oxford.

8. Hadžić, O. (2005): Primena koncepcije marketinga totalnog odnosa u kulturnom turizmu, magistarska teza, Prirodno-matematički fakultet, Univerzitet u Novom Sadu, Srbija.

9. Ljubojević, Č. (2002): Marketing usluga: Put ka potpunoj satisfakciji potrošača, Stylos, Novi Sad, Srbija.

10. Mattsson, L. G. (1997): Relationship Marketing and the Markets-as-Networks Approach-A Comparative Analysis of Two Evolving Streams of Research, Journal of Marketing Management, vol. 13, no. 5, pp. 447-462.

11. Mc Donald, R., Jolliffe, L. (2003): Cultural Rural Tourism-Evidence from Canada, Annals of Tourism Research, vol. 30, issue 2, pp. 307-322, Elsevier, Great Britain.

12. McKercher, B. (2004): A comparative study of international cultural tourists, vol. 11, no. 2, pp. 95-107, Journal of Hospitality and Tourism Management.

13. Nunnally, J. C. (1978): Psychometric theory, $2^{\text {nd }}$ edition, McGraw-Hill, New York.

14. Palmatier, R. W. (2008): Relationship Marketing, Marketing Science Institute, Cambridge.

15. Pavlović, N., Medić, S. (2014): Istraživanje relacija, interakcija i mreža ključnih stejkholdera kulturnog turizma u ruralnim područjima Vojvodine, anketno istraživanje, Novi Sad.

16. Popesku, J. (2014): Ključna pitanja razvoja ruralnog turizma, available at: http://www. cenort.rs/?page $\mathrm{id}=78$, accesed at: 15.03.2014.

17. Richards, G. (2013): Routledge Handbook of Cultural Tourism, Routledge, London.

18. Sheth, J., Parvatiyar, A. (2000): Handbook of Relationship Marketing, Sage Publications, California.

19. Stojanović, V. (2008): Priručnik za seoski turizam, poglavlje Prirodno okruženje i autentična kultura u seoskom turizmu, str. 57-78, Valjevo, Srbija.

20. Tylus, K. (2012): Culture as a Factor of Social and Economic Development - The Polish Experience, available at: http://poieinkaiprattein.org/economy/culture-and-economy/ culture-as-a-factor-of-social-and-economic-development---the-polish-experience-bykarolina-tylus, accessed at: 05.10.2014. 


\title{
RELACIJE, INTERAKCIJE I MREŽE STEJKHOLDERA KULTURNOG TURIZMA RURALNIH PODRUČJA VOJVODINE
}

\author{
Nataša Pavlovićc ${ }^{4}$ Sandra Medićc ${ }^{5}$ Aleksandra Tešičc
}

\begin{abstract}
Rezime
Savremeni tržišni uslovi, koje karakteriše izuzetno jak nivo konkurencije i zrelost većine tržišta, više nego ikada do sada, postaju suštinska pitanja uspešnosti turističkih destinacija. Ruralna područja u regionu Vojvodine zbog svoje multikulturalnosti imaju izrazite konkurentske prednosti na tršištu kulturnog turizma. Svaki učesnik koji kreira turistički proizvod u današnjem konkurentskom okruženju ima za cilj da se snažno usredsredi na satisfakciju potrošača, što ukazuju na neophodnost primene koncepta marketinga totalnog odnosa.

Cilj ovog rada je da prikaže na koji način ustanove kulture, proizvođači suvenira, turističke organizacije, agencije i ostali nosioce kulturne turisitčke ponude ostvaruju međusobnu saradnju i primenjuju savremeni koncept marketinga totalnog odnosa u svrhe zadovoljenja potreba potrošača - turista.

Putem ankentnog upitnika u radu će se istražiti osnovni postulati marketing odnosa koje primenjuju ključni stejkholderi kulturnog turizma u ruralnim područjima i dobiti referentni rezultati o relacijama, interakcijama i mrežama.
\end{abstract}

Ključne reči: marketing totalnog odnosa, kulturni turizam, ruralna područja.

4 Nataša Pavlović, Mr, zamenik direktora, Turistička organizacija Vojvodine, Bulevar Mihajla Pupina 6, 21000 Novi Sad, Srbija, Telefon: +381 63444 184, E-mail: nts.pavlovic@gmail.com

5 Sandra Medić, M.Sc, samostalni stručni saradnik, Turistička organizacija Vojvodine, Bulevar Mihajla Pupina 6, 21000 Novi Sad, Srbija, Telefon: +381 63535 599, E-mail: medics.ns@gmail.com

6 Prof. dr Aleksandra Tešić, Vanredni profesor, Univerzitet Privredna akademija, Fakultet za ekonomiju i inženjerski menadžment, Cvećarska 2, 21000 Novi Sad, Telefon: +381 692000 954, E-mail: prof.aleksandra.tesic@gmail.com

EP 2015 (62) 2 (481-495) 